\title{
Features of the budget and tax policy of the Russian Federation
}

\author{
Sergey Kolchin ${ }^{1, *}$, Nadezda Glubokova ${ }^{1}$, Mikhail Gordienko ${ }^{1}$ and Galina Dyakova ${ }^{2}$ \\ ${ }^{1}$ Plekhanov Russian University of Economics, 36, Stremyanny lane, 117997, Moscow, Russia \\ ${ }^{2}$ Russian New University, Radio str., 22, 105005, Moscow, Russia
}

\begin{abstract}
The purpose of the article is to analyze the main directions of the budget and tax policy of the Russian Federation, which is particularly relevant in view of the expected recession of the world economy due to the epidemic caused by the coronavirus (COVID-19) and the fall in world prices for hydrocarbon raw materials. In these circumstances, it is necessary to adjust the budget and tax policy in order to maintain the full social obligations of the state. The study used systematic, institutional approaches and statistical methods. The main conclusions of the work are based on the need to implement measures in the field of tax incentives for small and medium-sized businesses, for which the crisis phenomena have the most disastrous impact, and to maintain the planned amounts of budget funding for social programs. In the presence of sufficient accumulated gold and foreign exchange reserves and funds of the National Welfare Fund, it is possible and necessary to respond adequately and promptly to the changing economic situation in order to smooth its consequences on the level of inflation, unemployment and the purchasing power of the national currency.
\end{abstract}

\section{Introduction}

A comprehensive study of the current budget and tax policy of the Russian Federation should be conducted in the context of an economic downturn that is caused mainly by external factors. A systematic analysis of measures taken by financial authorities in the field of state regulation is therefore necessary to assess their effectiveness and develop proposals for improving financial policy at the macro level. This topic is particularly relevant in the current socio-economic situation, when many industries and sectors of the economy, especially small and medium-sized businesses, have been subjected to unexpected pressure. The purpose of the study is to analyze the impact of the economic downturn and develop proposals in the field of public financial policy for the short and possibly medium-term periods, which will help to smooth the negative impact of the crisis on the welfare of citizens and the financial stability of economic entities.

*Corresponding author: Sg6457@mail.ru 


\section{Methods and materials}

Federal law No. 380 "On the Federal budget for 2020 and for the planning period of 2021 and 2022" was adopted on the basis of the main directions of budget, tax, customs and tariff policy developed and approved by the Ministry of Finance of the Russian Federation [1].

The budget law reflects the main directions and priorities of the country's development in the short term. It is based primarily on the provisions of the Decree of the President of the Russian Federation of May 7, 2018 No. 204 "On national goals and strategic objectives for the development of the Russian Federation for the period up to 2024", and the key objectives stated in the Message of the President of the Russian Federation to the Federal Assembly of the Russian Federation of February 20, 2019.

The President of the Russian Federation has set quite ambitious goals: to achieve growth of the national economy above the world [3] through the development of new innovative technologies and digitalization, and on this basis to gain a foothold in the top five largest economies in the world; to increase GDP per capita in half by mid-decade; reduce poverty and achieve sustainable growth in real incomes; to increase life expectancy. Thus, the budget and tax policy is aimed at creating the necessary conditions for normal economic development.

Three scenarios for the forecast of socio-economic development of the Russian Federation were formed when preparing the budget: basic, conservative, and targetable [19]. Therefore, the basic scenario aimed at implementing the country's socio-economic development and ensuring budget sustainability was adopted as the basis.

The basic forecast assumes an increase in the share of fixed capital investment up to $25 \%$ of GDP, while oil prices will remain volatile, external sector sanctions from a number of foreign countries will be prolonged and a likely slowdown in the global economy and economic activity will remain. Budget security will likely continue to decrease depending on fluctuations in hydrocarbon prices, a stable exchange rate, and an acceleration of growth rates towards the end, primarily due to national projects. National projects are the most important tool for achieving the stated development goals. Approximately 13 trillion rubles are to be allocated from the federal budget (18 trillion rubles altogether) in the next 6 years for their implementation. Over the same period, the total amount of primary federal budget expenditures is expected to be 118 trillion rubles, and over 245 trillion rubles for the budget system as a whole.

When forming the main parameters of the 2020 budget, the legislator based on the volume of gross domestic product in the amount of 112,863 billion rubles and the inflation rate not exceeding $3.0 \%$, while in 2019 the values of these indicators were 108,414.0 billion rubles and $3.8 \%$, respectively [1,2]. In 2020, the inflation rate is expected to decrease, but in 2021 and 2022, inflation is projected at 4\%, corresponding to a growth rate of 5.3 percentage points. Compared to 2019, the GDP growth rate in 2020 is planned to be $4 \%$, revenues $-2 \%$, and expenditures - 5\%. In the 2020 budget it is planned to reduce the level of budget revenues from additional oil and gas revenues by $19 \%$. This is due to the trends in the world economy in the development of alternative energy sources, resourcesaving technologies, and a decline in economic activity in general, which objectively allows us to predict a fall in the price of Urals oil. According to the explanatory note to the draft federal budget, the average price of Urals oil in 2020 is set at $\$ 62.2$ dollars per barrel, in $2021-\$ 56$ dollars, and in $2022-\$ 55$ dollars.

The slight decrease in income relative to GDP is also explained by the forecast decline in oil prices. In addition to the negative price dynamics, the decline in the level of oil and gas revenues relative to GDP is influenced by the growth of tax incentives for the oil and gas sector. Thus, for 2019, the total amount of federal budget revenues in the amount of $19,970,279,674.2$ thousand rubles was set, including the projected amount of additional oil 
and gas revenues of the federal budget in the amount of 2,864,545,946. 1 thousand rubles, which was $14 \%$ of the total revenue, and in 2020 it is planned to reduce them to $11 \%$. As a result of these factors, the share of oil and gas revenues in total Federal budget revenues will decrease from $40.8 \%$ in 2020 to $35.0 \%$ in 2022 .

In general, that corresponds to the policy of reducing the budget's dependence on the oil and gas sector of the economy, whose position largely depends on the situation in world prices for hydrocarbons.

In 2020, the budget is formed with a surplus in the amount of 876,051,722. 0 thousand rubles or $0.8 \%$ of GDP, which in 2021 should be $0.5 \%$ of GDP, and in $2022-0.2 \%$ of GDP. The National Welfare Fund (NWF) is replenished from the budget surplus. The presence of a budget surplus is directly related to the effect of the budget rule, according to which all oil and gas revenues from oil prices above the base value set in the budget are placed in the Federal budget Fund.

Specific budget indicators $[2,1]$ are shown in table 1.

Table 1. Main characteristics of the federal budget in 2020-2022.

\begin{tabular}{|c|c|c|c|c|c|c|}
\hline Year & $\begin{array}{c}\text { Revenues (bn. } \\
\text { rb.) }\end{array}$ & $\begin{array}{c}\text { Expenditures } \\
\text { (bn. rb.) }\end{array}$ & $\begin{array}{c}\text { Surplus (bn. } \\
\text { rb.) }\end{array}$ & \multicolumn{3}{|c|}{$\begin{array}{c}\text { \% GDP revenues. } \\
\text { expenditures and } \\
\text { surplus budget } \\
\text { respectively }\end{array}$} \\
\hline $\begin{array}{c}2020 \text { (Law No. } \\
380 \text {-FZ) }\end{array}$ & 20379.3 & 19503.3 & 876.0 & 18.06 & 17.28 & 0.78 \\
\hline $\begin{array}{c}2020 \text { (Law No. } \\
459-F Z)\end{array}$ & 20218.6 & 18994.2 & 1224.3 & 18.1 & 17.3 & 0.8 \\
\hline $\begin{array}{c}2021 \text { (Law No. } \\
459 \text {-FZ) }\end{array}$ & 20978.0 & 20026.0 & 951.9 & 17.7 & 17.1 & 0.5 \\
\hline $\begin{array}{c}2021 \text { (Law No. } \\
\text { 380-FZ) }\end{array}$ & 21246.5 & 20634.0 & 612.5 & 17.6 & 17.1 & 0.5 \\
\hline $\begin{array}{c}2022 \text { (Law No. } \\
380-\text {-FZ) }\end{array}$ & 22058.2 & 21763.3 & 294.9 & 17.2 & 16.9 & 0.2 \\
\hline
\end{tabular}

Despite the surplus, the budget provides for an increase in public debt. The upper limit of the state internal debt of the Russian Federation as of January 1, 2021 is set at 12,981. 3 billion rubles, as of January 1, 2022-at 14,643. 7 billion rubles, and as of January 1, 2023 - at 16,619.3 billion rubles. The upper limits of the state external debt for this period are set in the amount of 64.4 billion us dollars ( 56.4 billion euros), 67.6 billion US dollars ( 57.8 billion euros) and 68.9 billion US dollars (57.4 billion euros), respectively.

The federal budget for 2020-2022 has a pronounced social character, which is reflected in the growth of expenditures on social programs and financial support for the Russian Federation's subjects. This budget is aimed at finding a balance between social spending and economic development.

The leading role in the budget is reserved for social expenditures, while the most significant expenditures are those on health care. In 2020, they will increase to 320 billion rubles (in 2019 - 160 billion rubles), while their growth will be provided by an additional increase in funding for the oncology subroutine, an increase in expenses for repairing clinics, as well as for training personnel. Altogether, $35 \%$ of expenditures, or almost 7 trillion rubles, will be spent on these areas over the next three years, while a significant part of expenditures will be financed from state social extra-budgetary funds, as well as from regional budgets.

Expenditures of budget funds by budget section in 2020 are shown in figure 1. 


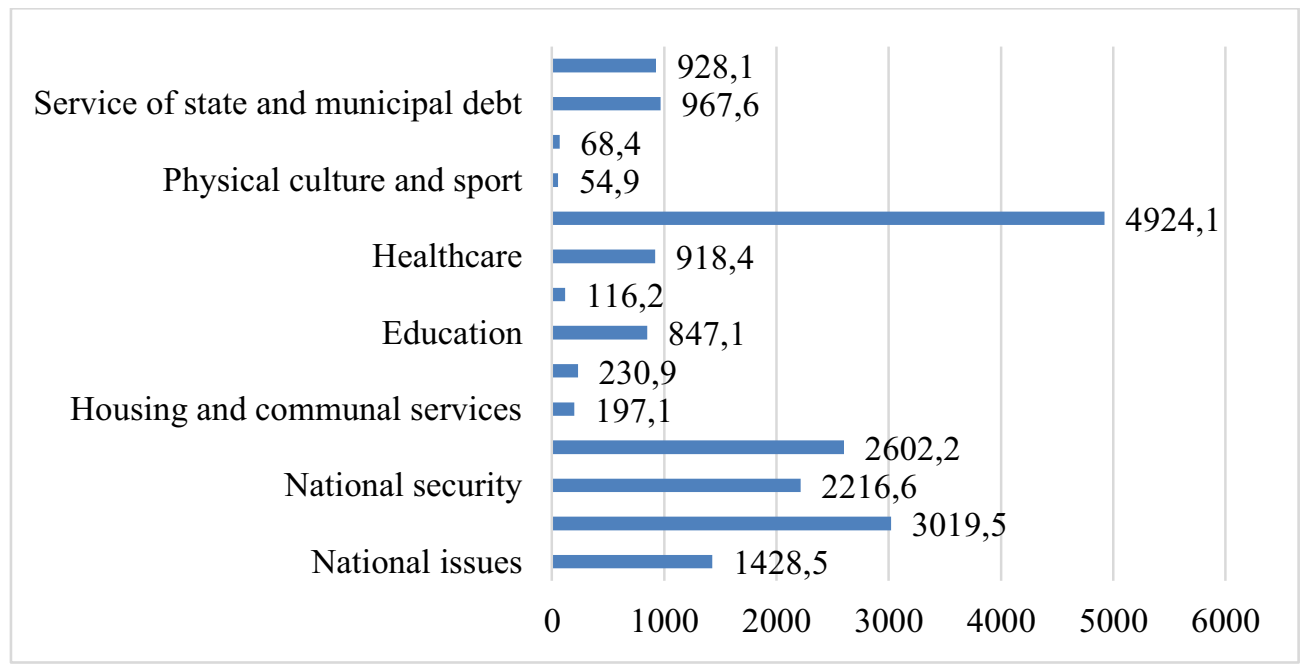

Fig. 1. Budget expenditures by budget section in 2020 (billion rubles) [5].

A significant part of the expenditure budget (almost $75 \%$ of all costs) is planned for implementation of state programs, for other areas of spending $-25 \%$, more than half of which $(63,8 \%)$ is for the development of the pension system.

Among other national projects, the year 2020 provided for an increase in expenditures on demographic projects - 616 billion rubles, education projects -126 billion rubles, science projects -514 billion rubles, cosmos projects - 107 billion rubles. Moreover, a separate support in the amount of 892 billion rubles is drafted for families, of which the funds of the parent capital amount to 316 billion rubles., payments in connection with the birth of the first child -150 billion rubles, and education -122 billion rubles. Social orientation of the budget is reflected in the increase in the minimum wage to 12.13 million rubles, which exceeds the rate of inflation [6]. At the same time, in the course of implementing the budget, significant adjustments were made in terms of increasing expenditures on the formation of maternity capital, child benefits and education.

As a result, the total share of expenditures in the social policy increased to $25.7 \%$, for the group of items "national economy" - decreased to $13.5 \%$, and for defense expenditures to $15.9 \%$

The main source of financing of budget expenditures is tax payment, and adequate tax burden (in combination with wise use of financial instruments) is a key feature of the national investment process $[14,15]$. Due to the increase in the main VAT rate from $18 \%$ to $20 \%$ and the improvement in the quality of tax administration, it is expected to increase revenues from one of the main sources of budget revenue - value added tax (VAT). In 2020 , it is planned to receive VAT in the amount of 7,502 trillion rubles.

The second most important tax revenue of the budget is the tax on mineral extraction, which is planned to be received in the amount of 6.036 trillion rubles, and the tax on the extraction of hydrocarbons accounts - 5.979 trillion rubles. In this relation, in order for the budget to be less dependent from such accounts, some researchers state that an increase in use of alternative energy resources (such as sun or wind energy) compared to traditional oil and gas might become a solution [17].

Income from income tax, excise taxes on imported goods and "import" duties for the period 2020-2022 as a share of GDP is projected within the framework of the methodology used by the Ministry of Finance at the level of 2019. However, budget revenues may be on average $0.1-0.2$ percentage points of GDP below the projected level, which may be caused, 
among other things, by overly optimistic expectations about the dynamics of excise taxes on goods produced within the country.

\section{Results}

Planning a budget surplus in the context of low GDP growth is subject to reasonable criticism by many experts. According to estimates of the Ministry of Finance of the Russian Federation and the state Duma Committee on budget and taxes, the optimal value of the National Welfare Fund should eventually amount to 7\% of GDP. Thus, almost all GDP growth over 3-4 years is sterilized, which objectively reduces the investment potential of the economy. The reallocation of financial resources from the real sector of the economy to the sovereign fund clearly does not contribute to achieving the goals set out in the budget policy goals.

At the same time, the federal budget provides for an increase in public debt, which seems quite inexplicable. The purpose of issuing federal loan bonds with a high level of yield is not clear, while the funds of the federal reserve are placed very conservatively with a minimum yield. At the same time, the state has significant financial resources at its disposal from the growth of taxes and improving their collection, including from the extraction of hydrocarbons, which, according to the budget rule, are not allocated to finance public expenditures. The cash surplus is growing as the cash gap widens. Prime Minister Mikhail Mishustin at a Government meeting, commenting on the report of the accounts chamber of the Russian Federation on budget execution for 2019, noted that the amount of undeveloped funds, which amounted to about 1.1 trillion rubles for 2019 , is unacceptably large [8].

It was also difficult to find sufficient justification for the increase in taxes on business and the population. Thus, VAT has increased by two percentage points, the procedure for determining the tax base for the property tax of individuals has been changed, excise tax rates are indexed annually, the number of vehicles that can be subject to increasing coefficients for transport tax has been increased, taxation of the self-employed population has been introduced, and it is planned to abolish imputed taxation for small and mediumsized businesses from 2021. Despite the negative reaction of the business community, it is planned to transform non-tax revenues (recycling fee, mandatory deductions of public communication network operators, resort fee) into the Tax Code. At the same time, plans to improve tax policy do not consider the transition to progressive taxation of individuals, which could ease the tax burden on low-income citizens.

However, the events of the beginning of 2020 show that the failure of budget execution in the new conditions is highly probable according to the basic forecast.

Due to the coronavirus pandemic, the economy of the United States and some EU countries entered a recession, and the expected growth of the Chinese economy does not show, which negatively affected the world markets for hydrocarbons. The breakup of the OPEC + deal and the subsequent increase in production volumes, which created an oversupply in the oil market, contributed to the unpredictable fall in oil prices. The dynamics of falling oil prices is shown in figure 2. 


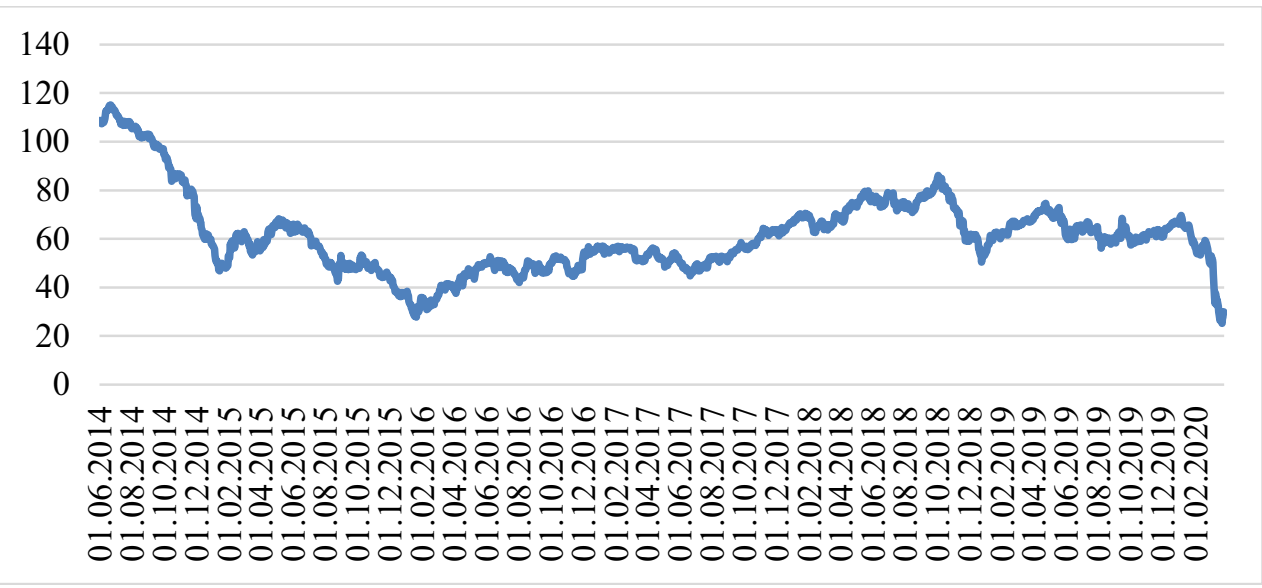

Fig. 2. Chart of world oil price quotes (\$ per barrel) [9].

Boris Titov, the presidential Commissioner for the protection of entrepreneurs rights, described the current economic situation in Russia as critical. He noted that there was no such negative combination of external and internal factors in1998 and 2014: "... the desert. The only real option is to go back to the state economy $<\ldots>$ to take everything under state control, this can stabilize the situation for some time, in order to avoid starvation, completely wild manifestations of the economic crisis" [10].

Following an unprecedented drop in oil prices, the national currency collapsed, as shown in figure 3 [17].

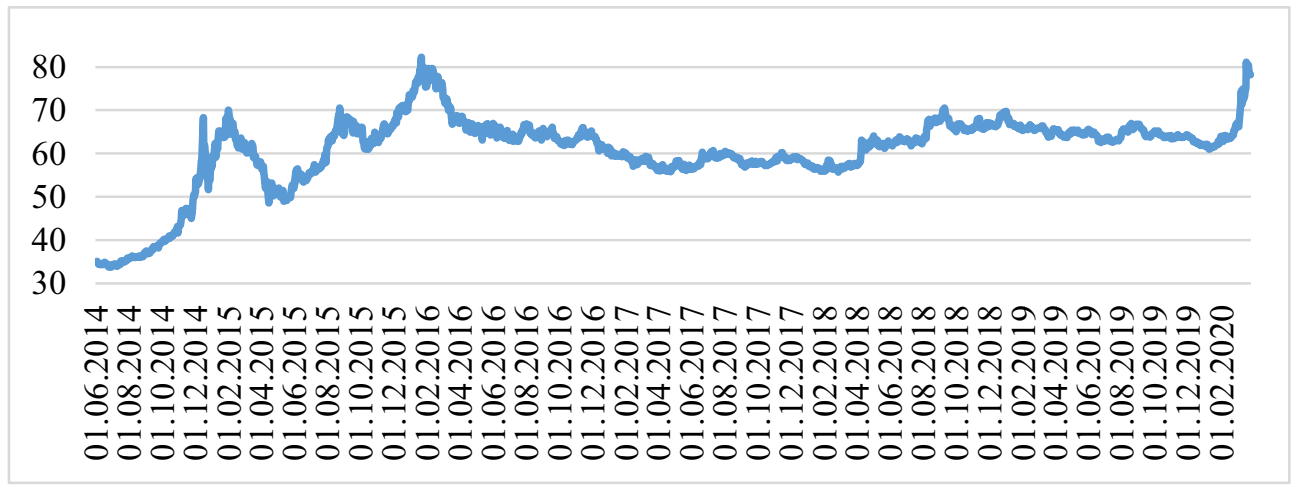

Fig. 3. Chart of quotations of the ruble against the us dollar (rubles per \$1) [9].

As a result, the budget execution forecasts for expenditures have been revised. At a meeting of the Federation Council, Finance Minister Anton Siluanov said that the Russian budget deficit will be $0.9 \%$ of GDP instead of the previously expected surplus of $0.8 \%$, but all spending obligations will be met. According to the Ministry of Finance, at current prices for raw materials, oil and gas revenues may decrease by about 2 trillion rubles [11].

On the Vesti program, Siluanov said: "we have enough reserves of strength to finance all our obligations, and not just social ones. At the current price proportions in the oil market, such reserves will last for at least six years. From the point of view of fulfilling priority obligations, these are salaries, pensions, benefits, there is no reason to talk about changing the payment procedure, we will fully comply with them" [12].

In these conditions, the "airbag" in the form of the NWF, the volume of which exceeded 8 trillion $\mathrm{rb}$. this year will be useful. 


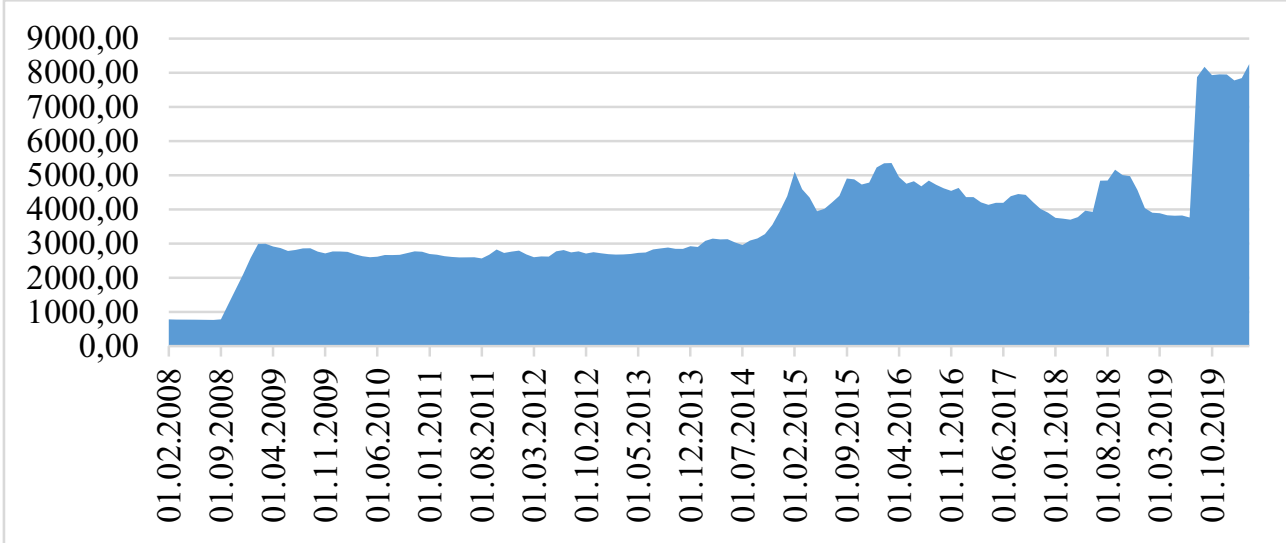

Fig. 4. Dynamics of the volume of the national welfare Fund (billion rubles) [13].

\section{Discussion}

However, the real economic situation in the country does not inspire optimism. The effect of the downward spiral of economic activity reduces demand for goods and services, affects the purchasing power of the national currency, negatively affects small and medium-sized businesses and enterprises focused on imported raw materials and components [15].

Under the threat of bankruptcy was the least financially stable small business. Quarantine measures have a strong negative impact on the profitability of small enterprises in the field of public catering, tourism and hotel business, in the sports and transport industry, in enterprises engaged in cultural and recreational activities, advertising, leisure activities, etc.

Companies that use imported raw materials and components are experiencing difficult times due to the collapse of the national currency.

This situation is fraught with an increase in unemployment and poverty, an increase in social and internal political tensions, a decrease in the birth rate and other negative social consequences.

It is unpredictable when the coronavirus pandemic will go down, which will allow the lifting of quarantine restrictions. Some experts believe that the decline may not occur earlier than a year.

In the current force majeure conditions, the depth of the recession and the speed of subsequent economic recovery directly depend on the effectiveness of the state financial policy.

\section{Conclusions}

The current situation requires prompt government intervention, including the use of fiscal policy tools.

From the point of view of budget policy, it is necessary to provide additional funding for medicine, introduce subsidies for low-income and at-risk groups of the population, expand social support for families with children, and provide state guarantees for loans to the population.

Tax policy should be based on expanding benefits and preferences for small businesses and import-oriented industries. First of all it is necessary: 
1. Establish temporary tax holidays for small businesses that have lost customers due to quarantine measures, for the entire set of tax payments and fees charged.

2. Introduce temporary exemption of these enterprises for deductions to social extrabudgetary funds, provided that the staffing table is maintained at the pre-crisis level.

3. Temporarily abolish the professional income tax and the unified tax under the patent taxation system.

4. Introduce a moratorium on the payment of penalties for tax arrears, followed by debt cancellation.

5. Suspend the collection of penalties.

6. To cancel the tax control measures in respect of small businesses.

7. Introduce additional tax incentives for corporate property tax and profit tax for import-oriented manufacturing enterprises, up to the establishment of zero tax rates on a temporary basis.

8. Expand the possibility of changing the timing of tax obligations in the form of deferrals or installments for businesses with financial instability that arose as a result of the crisis.

\section{References}

1. Federal law of 02.12.2019 No. 380-FZ On the Federal budget for 2020 and for the planning period of 2021 and 2022"

2. Federal law of 29.11.2018 No. 459-FZ On the Federal budget for 2019 and for the planning period of 2020 and 2021"

3. Message of the President of the Russian Federation to the Federal Assembly of the Russian Federation dated February 20, 2019

4. Resolution of the Government of the Russian Federation dated 24.12.2019 No. 1803. Official website of the Ministry of Finance of Russia https://www.minfin.ru/ru/document/?id_4=129356-

postanovlenie pravitelstva_rossiiskoi_federatsii_ot_24.12.2019_1803_ob_osobennost yakh_ryealizatsii_federalnogo_zakona_o_federalnom_byudzhete_na_2020_god_i_na_ planovyi_period

5. Main directions of budget, tax, customs and tariff policy for 2020 and for the planning period of 2021 and 2022"(approved Ministry of Finance of Russia)

6. Explanatory note to the draft Federal law On the Federal budget for 2019 and for the planning period of 2020 and 2021"

7. Draft Federal law no. 802503-7 On the Federal budget for 2020 and the planning period of 2021 and 2022"

8. Mishustin called the unspent part of the budget unacceptably large. Online publication RIA Novosti https://ria.ru/20200220/1565001914.html

9. L. Shabalina, L. Kopteva, A. Mottaeva, E3S Web of Conferences 175, 13040 (2020) https://doi.org/10.1051/e3sconf/202017513040

10. Titov called the economic crisis in Russia more serious than the default of 98. Official website of the radio station Govorit Moskva'https://govoritmoskva.ru/news/228952/

11. L.N. Nikolova, D.G. Rodionov, M.A. Bahauovna, International Journal of Economics and Financial 6(2), 246-252 (2016)

12. E. Vasilyeva, A. Mottaeva, E3S Web of Conferences 91, 08051 (2019) doi.org/10.1051/e3sconf /20199108051 
13. The volume of Fund of national well-being. Statistics. Official website of the Ministry of Finance of Russia https://www.minfin.ru/ru/perfomance/nationalwealthfund/statistics/?id_65=27068obem_fonda_natsionalnogo_blagosostoyaniya

14. R.G. Akhmadeev, M.E. Kosov, O.A. Bykanova, K.V. Ekimova, S.V. Frumina, N.V. Philippova, Journal of Applied Economic Sciences 11(5), 992-1002 (2016)

15. A.Y. Annenkov, I.B. Khmelev, I.V. Sokolnikova, O.N. Ilina, International Journal of Civil Engineering and Technology 10(2), 1892-1898 (2019)

16. M.E. Kosov, R.G. Akhmadeev, O.A. Bykanova, V.S. Osipov, K.V. Ekimova, S.V. Frumina, Journal of Applied Economic Sciences 11(8), 1613-1623 (2016)

17. N.V. Ponomareva, A.O. Zvereva, E.V. Golubtsova, S.B. Ilyashenko, International Journal of Energy Economics and Policy 9(4), 144-148 (2019) doi:10.32479/ijeep.7964

18. D.S. Zakharova, A.U. Soltakhanov, O.A. Zhdanova, K.K. Arabyan, Espacios 39(18), 15 (2018)

19. N. Elsebaie, E. Ganebnykh, M. Lunyakov, E3S Web of Conferences 110, 02155 (2019) DOI: $10.1051 / \mathrm{e} 3$ sconf $/ 201911002155$ 